\title{
Written records of historical tsunamis in the northeastern South China Sea - challenges associated with developing a new integrated database
}

\author{
A. Y. A. Lau ${ }^{1}$, A. D. Switzer ${ }^{2}$, D. Dominey-Howes ${ }^{3}$, J. C. Aitchison ${ }^{1}$, and Y. Zong ${ }^{1}$ \\ ${ }^{1}$ Department of Earth Sciences, The University of Hong Kong, Hong Kong SAR, China \\ ${ }^{2}$ Earth Observatory of Singapore, Nanyang Technological University, Singapore \\ ${ }^{3}$ Australian Tsunami Research Centre and Natural Hazards Research Laboratory, University of New South Wales, Sydney, \\ NSW 2052, Australia
}

Received: 15 December 2009 - Revised: 9 June 2010 - Accepted: 10 June 2010 - Published: 1 September 2010

\begin{abstract}
Comprehensive analysis of 15 previously published regional databases incorporating more than 100 sources leads to a newly revised historical tsunami database for the northeastern (NE) region of the South China Sea (SCS) including Taiwan. The validity of each reported historical tsunami event listed in our database is assessed by comparing and contrasting the information and descriptions provided in the other databases. All earlier databases suffer from errors associated with inaccuracies in translation between different languages, calendars and location names. The new database contains 205 records of "events" reported to have occurred between AD 1076 and 2009. We identify and investigate 58 recorded tsunami events in the region. The validity of each event is based on the consistency and accuracy of the reports along with the relative number of individual records for that event. Of the 58 events, 23 are regarded as "valid" (confirmed) events, three are "probable" events and six are "possible". Eighteen events are considered "doubtful" and eight events "invalid". The most destructive tsunami of the 23 valid events occurred in 1867 and affected Keelung, northern Taiwan, killing at least 100 people. Inaccuracies in the historical record aside, this new database highlights the occurrence and geographical extent of several large tsunamis in the NE SCS region and allows an elementary statistical analysis of annual recurrence intervals. Based on historical records from 1951-2009 the probability of a tsunami (from any source) affecting the region in any given year is relatively high (33.4\%). However, the likelihood of a tsunami that has a wave height $>1 \mathrm{~m}$, and/or causes fatalities and damage to infrastructure occurring in the region in any given year is low (1-2\%). This work indicates the need for further research
\end{abstract}

Correspondence to: A. D. Switzer (aswitzer@ntu.edu.sg) using coastal stratigraphy and inundation modeling to help validate some of the historical accounts of tsunamis as well as adequately evaluate the recurrence intervals of tsunamis along the now heavily developed coastlines of the region.

\section{Introduction}

The South China Sea (SCS) is located along the southeastern edge of the Eurasian Plate between $99-122^{\circ} \mathrm{E}$ and 0 $25^{\circ} \mathrm{N}$. Its primary physiography consists of a deep basin (up to $5400 \mathrm{~m}$ deep) and two large shallow continental shelves on the northern and southwestern margins. In the northeast, the SCS connects to the East China Sea (ECS) through the Taiwan Strait (TS), and to the Pacific Ocean through the Luzon Strait (LS) (Fig. 1).

This investigation is focused upon the NE SCS, and includes the passive southeast margin of Eurasia and the arccontinent collision zone of Taiwan (Teng, 1990). The island of Taiwan lies on the junction of the Luzon and Ryukyu island arcs where the Ryukyu arc overrides the Philippine Plate to the east of Taiwan, and the Eurasian Plate subducts beneath the Philippine Plate to the south (Suppe, 1984). The Taiwan Strait, a shallow shelf channel more than $300 \mathrm{~km}$ in length, lies to the west of Taiwan.

Intense seismic activity owing to the presence of convergent plate boundaries around Taiwan and Luzon combined with volcanism in the western Pacific, suggests that the region is likely to have been subject to a considerable number of tsunamis throughout history. However, our knowledge of the regional tsunami history remains incomplete, fragmentary and often contradictory presenting an obstacle for properly understanding the regional risk and to developing effective tsunami risk management strategies. 


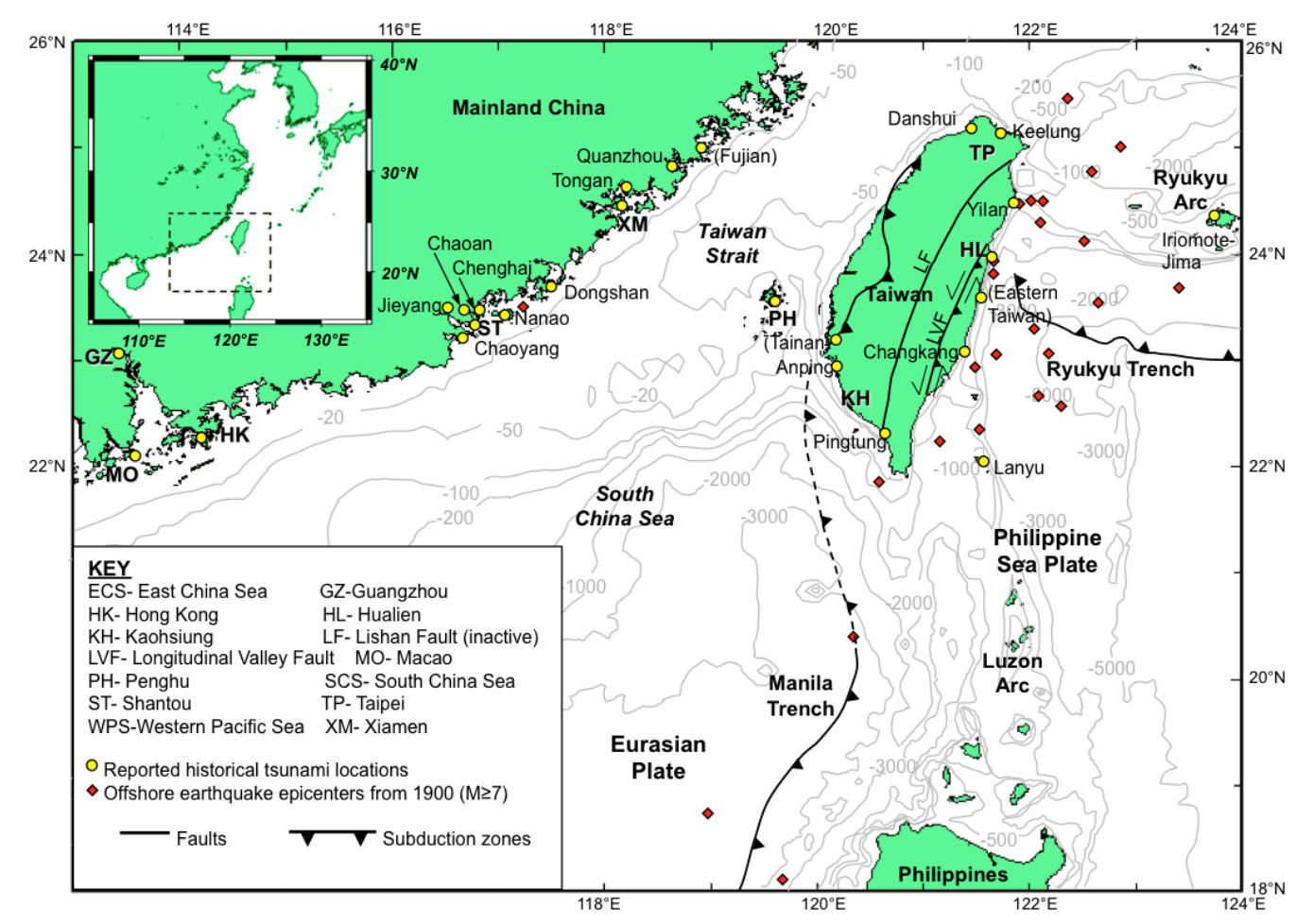

Fig. 1. Map of the NE South China Sea and surrounding regions. Locations of main cities are denoted with abbreviated names. Reported places affected by historical tsunamis are marked with yellow circles along with full names. Names in brackets represent the less defined locations, for which the locations marked with yellow circles may not be the exact part of coast affected due to the lack of details reported. (Bathymetry modified from Jan et al., 2002, and NGDC, 2009a; tectonics adapted from Shyu, 2006; earthquake epicenters data adapted from Zhang, 2002, and NGDC, 2009b.)

One notable example is the 1782 tsunami, which is reported to have killed more than 40000 (Soloviev and Go, 1974). This tsunami is also listed by Bryant (2008) as resulting in "the second largest death toll from tsunami in the Pacific and Indian Oceans over the last 2000 years". Bryant (2008) states that this tsunami claimed some 50000 lives, out ranked only by the 2004 Indian Ocean disaster. However, there is little Chinese literature reporting such a disastrous event, hence its occurrence should be the subject of more detailed study and analysis. Such notable contradictions indicate the need to develop a detailed historical database of regional tsunamis.

The aim of this study is to identify, collate and cross-check previous accounts of historic tsunamis in order to establish a new database of historical regional tsunamis. For each identified event, a new validity score based upon a comparison of the details contained in a range of original sources is given. A variety of issues and difficulties associated with the compilation of historical records of past tsunamis are identified. The database generated can guide future field-based work on palaeotsunamis and assist in verifying and assessing the potential impacts of recorded historical tsunamis and in the identification of regionally significant events (Goff and Dominey-Howes, 2009).

\subsection{Tsunami databases}

Historical tsunami databases or catalogues (hereafter referred to as "databases") have been compiled for many regions since the development of the first historical tsunami catalogue by Heck $(1934,1947)$ (Gusiakov, 2009). Over 120 catalogues are recorded in the list of "tsunami catalogs" by Novosibirsk Tsunami Laboratory (NTL) available online at http://tsun.sscc.ru/tsulab/tsu_catalogs.htm. Nevertheless, many databases are not comprehensive enough to provide a complete tsunami history of the areas they cover. A detailed and accurate database should systematically include data compiled from a range of sources as extensively as possible. Regional databases have been compiled for the Mediterranean Sea, Caribbean, Australia and the western Pacific. Some examples of historical tsunami databases are listed in Table 1.

Besides these regional databases, global tsunami databases have also been developed. In recent decades, computerized tsunami databases have been made available online, making historical tsunami information more accessible. One of the most widely used online databases is that compiled and managed by the US National Geophysical Data Center (NGDC), National Oceanic and Atmospheric Administration (NOAA). 
Table 1. Examples of regional tsunami databases/catalogues from other areas around the world.

\begin{tabular}{lll}
\hline Region & Title of database/catalogue & Reference \\
\hline Australia & Geological and historical records of tsunami in Australia & Dominey-Howes (2007) \\
Caribbean & The Caribbean Tsunami History & O'Loughlin and Lander (2003) \\
Guam (western Pacific) & The Tsunami History of Guam: 1849-1993 & Lander and Whiteside (2002) \\
Mediterranean Sea & Tsunamis in the Mediterranean Sea 2000 BC-2000 AD & Soloviev et al. (2000) \\
New Zealand & The New Zealand Palaeotsunami Database & Goff (2008) \\
United Status (Eastern) & Tsunamis and tsunami-like waves of the Eastern United States & Lockridge et al. (2002) \\
World-wide & List of Tsunamis by International Tsunami Information Centre (ITIC) & ITIC (2010) \\
\hline
\end{tabular}

The NGDC tsunami database remains the most frequentlycited historical tsunami data source (Gusiakov, 2009). However, Gusiakov (2009) noted that due to the wide-range of data sets used to develop this global database, more checking of the accuracy and refinement of information is required, along with new work to match existing data to more recently published research.

Where historical databases are sufficiently long that they capture the range of tsunami magnitudes that can occur, the recurrence interval and nature of the tsunami hazard for a region can be defined (O'Loughlin and Lander, 2003; Dominey-Howes, 2002). They can guide decision making related to land-use zoning policies, the development of building codes and standards, the development and deployment of early warning systems and be used to raise awareness of the general public through outreach and education.

A notable example is the database developed for New Zealand by Goff (2008). This includes both historical and palaeotsunamis and provides an assessment of validity of each event. As local written records of tsunamis affecting New Zealand only extend back to the early 19th century, palaeotsunamis are also reported. The palaeotsunami record is based on sedimentary, geomorphological, archaeological and anthropological evidence. In contrast, the NE region of the SCS has a long historical record that, once carefully validated, may be compared to palaeotsunami records from the region.

Another frequently cited tsunami database is the Caribbean 500-year tsunami history (O'Loughlin and Lander, 2003). In contrast to the New Zealand database, the Caribbean historical tsunami database was developed purely on information obtained from published sources. A tsunami validity rating was also developed for this database based upon the perceived accuracy of the original sources. Judgments about the accuracy of tsunami reports and the reliability of information sources are essential for developing a coherent and accurate database. This is particularly the case in China where ancient tsunami records can possibly be traced back more than 2000 years.

The earliest record of a tsunami-like event in China is recorded as a "sea-surge" that occurred with an earthquake (...地再動, 北海水溢流...; partial translation: moving seawater overflow) at Laizhou Bay, Bohai in $47 \mathrm{BC}$ (Lu, 1984). This event is recorded in several Chinese dynasty and county records (e.g. < 前漢書; translation: Former Han Records $>$, cited by Lu, 1984). However, written records of tsunamis in China are inconsistent, fragmented and overinterpreted, problems that are common amongst historical data (Dominey-Howes, 2002; Goff, 2008; Gusiakov, 2009). In order to construct a comprehensive database for the region, information from 15 existing tsunami databases was collated. The sources include global tsunami databases, and regional tsunami information from more than 100 sources for China and the South China Sea in both Chinese and English (Table 2).

\section{Methods}

A standard approach modified from O'Loughlin and Lander (2003) and Goff (2008) is adapted in this study. The validity of each proposed event is assessed by comparing information and descriptions provided in the original source databases (primary sources). For this purpose, two tables (Tables S1 and 3) were created for clear presentation. Tables S1 mimics the format of Goff (2008). Each horizontal line in the database relates to a single event. For each event, a series of columns provide information about that event where available. Information listed is directly taken from the 15 databases, even when there are contradictions or irrational descriptions. The names of places have been standardized to official contemporary names, since a variety of translated names were found in the past records. Under the column "References", all references (secondary sources) cited for each reported event by the source databases are included. Such details are used for validity assessment and to provide background information for further study of these events.

Table 3 is an abbreviated version of Table S1 that displays a basic list of reported events. Assessment of validity is made with reference to the validity rating parameters of the Caribbean Tsunami History of O'Loughlin and Lander (2003) (Table 4). The assessment scheme of O'Loughlin and Lander (2003) is primarily based on the scale by Iida (1984). The date, location, wave height and 
Table 2. List of source catalogues and publications containing tsunami data of the region used in this study.

\begin{tabular}{|c|c|c|}
\hline No. & Title of publication & Area concerned \\
\hline 1 & $\begin{array}{l}\text { Tsunamis (Cheng, 1965) } \\
\text { [Table: The effect of recent tsunamis on Hong Kong] }\end{array}$ & Hong Kong \\
\hline 2 & $\begin{array}{l}\text { Preliminary Catalog of Tsunamis Occurring in } \\
\text { the Pacific Ocean (Iida et al., 1967) }\end{array}$ & Pacific Ocean \\
\hline 3 & $\begin{array}{l}\text { Tsunamis and seismic seiches of Southeast Asia } \\
\text { (Berninghausen, 1969) }\end{array}$ & Southeast Asia \\
\hline 4 & $\begin{array}{l}\text { A Catalogue of Tsunamis on the Western Shore of } \\
\text { the Pacific Ocean (Soloviev and Go, 1974) }\end{array}$ & $\begin{array}{l}\text { Western shore of } \\
\text { Pacific Ocean }\end{array}$ \\
\hline 5 & $\begin{array}{l}\text { China Earthquakes (Li, 1981) } \\
\text { [Table of "Chinese historical tsunami record"] (in Chinese) }\end{array}$ & $\begin{array}{l}\text { China (Mainland China } \\
\text { and Taiwan) }\end{array}$ \\
\hline 6 & $\begin{array}{l}\text { Tsunamigenic earthquakes in China: } 1831 \text { BC-1980 AD } \\
\text { (Zhou and Adams, 1986) [Table: Tsunamis in China, } 47 \text { BC-1978 AD] }\end{array}$ & $\begin{array}{l}\text { China (Mainland China } \\
\text { and Taiwan) }\end{array}$ \\
\hline 7 & $\begin{array}{l}\text { Tsunami and Pacific tsunami warning system (Yang, 1987) } \\
\text { [Table: Chinese historical tsunami list] (in Chinese) }\end{array}$ & $\begin{array}{l}\text { China (Mainland China } \\
\text { and Taiwan) }\end{array}$ \\
\hline 8 & $\begin{array}{l}\text { Report of Hong Kong in the International Tsunami Seminar in the Western Pacific } \\
\text { Region In International Tsunami Seminar in the Western Pacific Region (Lee, 1988) } \\
\text { [Table: Historical events in the northern part of the South China Sea } \\
\text { which were certainly or probably tsunamigenic] }\end{array}$ & $\begin{array}{l}\text { Northern part of } \\
\text { South China Sea }\end{array}$ \\
\hline 9 & $\begin{array}{l}\text { Destructive Earthquake Tsunamis in the Ming and Ching Eras } \\
\text { (Yü, 1994) [Tables: Mainland China historical tsunami record/ } \\
\text { Taiwan historical suspected tsunamigenic earthquake record] (in Chinese) }\end{array}$ & $\begin{array}{l}\text { Mainland China and } \\
\text { Taiwan }\end{array}$ \\
\hline 10 & $\begin{array}{l}\text { Earthquake Tsunami Record in Chinese Ancient Books (Wang et al., 2005) } \\
\text { [Chapter: Examples of earthquake tsunami in China] (in Chinese) }\end{array}$ & $\begin{array}{l}\text { Mainland China and } \\
\text { Taiwan }\end{array}$ \\
\hline 11 & $\begin{array}{l}\text { Preliminary research on the development of tsunami warning system } \\
\text { at northeastern Taiwan (Li et al., 2006) } \\
\text { [Section: Tsunamis at Taiwan and nearby areas] (in Chinese) }\end{array}$ & $\begin{array}{l}\text { Taiwan, } \\
\text { mainland China, } \\
\text { and Japan }\end{array}$ \\
\hline 12 & $\begin{array}{l}\text { Likelihood of Tsunamis Affecting the Coast of Southeastern China } \\
\text { [Table: Earthquakes in the northern part of the South China Sea } \\
\text { that were probably tsunamigenic] }\end{array}$ & $\begin{array}{l}\text { Northern part of } \\
\text { South China Sea }\end{array}$ \\
\hline 13 & $\begin{array}{l}\text { Historical tsunamis in South China (Mak and Chan, 2007) } \\
\text { [Table: Suspected tsunami events extracted from previous tsunami surveys] }\end{array}$ & South China Sea \\
\hline 14 & $\begin{array}{l}\text { NOAA/WDC Historical Tsunami Database at NGDC } \\
\text { ( } 2000 \mathrm{BC} \text { to present) }\end{array}$ & Worldwide \\
\hline 15 & $\begin{array}{l}\text { Historical Tsunami Database for the World Ocean by NTL } \\
\text { (1628 BC to present) }\end{array}$ & Worldwide \\
\hline
\end{tabular}

death toll of each recorded tsunami are summarized in this table. Each tsunami report was cross-checked against reports in other databases for the same event. Validity scores assigned are based upon (1) judged credibility of the cited materials; (2) consistency of data and reported details from different databases; (3) the number of source catalogues recording the event; (4) evidence of logical thought and clarity of descriptions; (5) accuracy in referencing and interpretation of cited materials and (6) comments made and validity scores given to each event by researchers compiling the source catalogues.

\section{Results}

From the 15 source databases reviewed, a total of 205 descriptions of tsunamis are noted (Table S1). Once validity assessment was completed, 58 individual possible tsunami events were recognized (Table 3). The earliest reported event in the region is recorded as a sea surge at Haiyang (presently Chao'an) and Chaoyang in 1076, and the most recent being a 2006 tsunami caused by an earthquake south of Taiwan (Fig. 1). While two events were reported in 12 out of 15 databases, 18 were recorded in just one database. Events with limited documentation are mostly erroneously reported or recent events that were not covered in older databases. 
Table 3. A database of historical tsunamis in the NE South China Sea region with validity score assigned. Validity score - 0: Invalid, 1: Doubtful, 2: Possible, 3: Probable, 4: Valid. Source database - 1: Cheng (1965), 2: Iida et al. (1967), 3: Berninghausen (1969), 4: Soloviev and Go (1974), 5: Li (1981), 6: Zhou and Adams (1986), 7: Yang (1987), 8: Lee (1988), 9: Yü (1994), 10: Wang et al. (2005), 11: Li et al. (2006), 12: Wong and Chan (2006), 13: Mak and Chan (2007), 14: NGDC database, 15: NTL database.

\begin{tabular}{|c|c|c|c|c|c|c|c|c|}
\hline $\begin{array}{l}\text { Event } \\
\text { No. } \\
\text { (\#) }\end{array}$ & $\begin{array}{r}\text { Date } \\
(\mathrm{GMT}+8)\end{array}$ & $\begin{array}{l}\text { Reported } \\
\text { Tsunami } \\
\text { Location }\end{array}$ & $\begin{array}{l}\text { Reported } \\
\text { Source } \\
\text { Location }\end{array}$ & $\begin{array}{l}\text { Vali- } \\
\text { dity }\end{array}$ & $\begin{array}{l}\text { Max. water } \\
\text { height } \\
\text { (m) }\end{array}$ & Death toll & $\begin{array}{l}\text { Remarks/ } \\
\text { comments }\end{array}$ & $\begin{array}{l}\text { Source } \\
\text { databases }\end{array}$ \\
\hline 1 & 31 Oct 1076 & $\begin{array}{l}\text { Chao-an } \\
\text { (former Haiyang), } \\
\text { Chaoyang } \\
\text { (Guangdong) }\end{array}$ & $\begin{array}{l}\text { South China } \\
\text { Sea (SCS) }\end{array}$ & 1 & & "People died" & $\begin{array}{l}\text { "Probably storm } \\
\text { surge" }\end{array}$ & $\begin{array}{l}2,4,5,11 \\
13,14,15\end{array}$ \\
\hline 2 & 1 Aug 1353 & Quanzhou (Fujian) & & 1 & & & & 5,11 \\
\hline 3 & 29 Dec 1604 & Quanzhou (Fujian) & Fujian & 1 & & & & $\begin{array}{l}6,7,8,10 \\
11,12,13,14\end{array}$ \\
\hline 4 & $\begin{array}{r}16 \text { Sep } \\
14 \text { Oct } 1640\end{array}$ & $\begin{array}{l}\text { Jieyang, Chenghai, } \\
\text { Chaoyang (Shantou, } \\
\text { Guangdong) }\end{array}$ & Guangdong & 2 & & & & $\begin{array}{l}2,3,4,5 \\
7,8,9,11 \\
13,14,15\end{array}$ \\
\hline 5 & $\begin{array}{r}16 \text { Sep } \sim \\
26 \text { Nov } 1641\end{array}$ & $\begin{array}{l}\text { Chenghai, Chaoyang } \\
\text { (Guangdong) }\end{array}$ & Guangdong & 1 & & & & $6,7,11,13$ \\
\hline 6 & 1660 & $\begin{array}{l}\text { ? (Source at South } \\
\text { China Sea) }\end{array}$ & SCS & 0 & & & & 3,14 \\
\hline 7 & Jan $\sim$ Feb 1661 & Anping (Tainan) & Tainan & 1 & 1 & & & $\begin{array}{l}2,3,4,6 \\
7,8,9,11 \\
12,13,14,15\end{array}$ \\
\hline 8 & Dec 1682 & $\begin{array}{l}\text { ? (Source at South } \\
\text { China Sea) }\end{array}$ & SCS & 0 & & & & 14 \\
\hline 9 & 5 Jan 1721 & Tainan & Tainan & 1 & & & $\begin{array}{l}\text { "Unusual wind } \\
\text { and rainstorm" }\end{array}$ & 9,11 \\
\hline 10 & Sep 1721 & Tainan & Tainan & 1 & & "Thousands" & $\begin{array}{l}\text { "Strange wind } \\
\text { and rainstorm" }\end{array}$ & $\begin{array}{l}6,7,8,11 \\
13,14\end{array}$ \\
\hline 11 & Apr 1754 & Danshui (Taipei) & $\begin{array}{l}\text { Danshui/East } \\
\text { China Sea (ECS) }\end{array}$ & 2 & & & & $4,7,11,14,15$ \\
\hline 12 & May 1765 & $\begin{array}{l}\text { Guangzhou } \\
\text { (Guangdong) }\end{array}$ & SCS & 1 & $9(?)$ & 10000 & $\begin{array}{l}\text { "Possibly } \\
\text { meteorological" }\end{array}$ & $\begin{array}{l}2,3,4,8 \\
13,14,15\end{array}$ \\
\hline 13 & 22 Nov 1767 & Macau & Macau & 1 & & & Same event as \#12? & $\begin{array}{l}3,4,8,13 \\
14,15\end{array}$ \\
\hline 14 & Apr Jun 1781 & $\begin{array}{l}\text { Kaohsiung, } \\
\text { Pingtung }\end{array}$ & $\begin{array}{l}\text { "Distant earthquake"/ } \\
\text { Taiwan }\end{array}$ & 1 & $\begin{array}{l}>30 \text { (few tens } \\
\text { of "zhang") }\end{array}$ & $\begin{array}{c}1 \text { or } \\
>50000\end{array}$ & & $\begin{array}{l}7,9 \\
11,13\end{array}$ \\
\hline 15 & 22 May 1782 & $\begin{array}{l}\text { Kaohsiung, Taiwan } \\
\text { Strait coasts }\end{array}$ & SCS & 1 & 10 & $>40000$ & $\begin{array}{l}\text { "Possibly } \\
\text { meteorological" }\end{array}$ & $2,4,13,14,15$ \\
\hline 16 & 9 Aug 1792 & $\begin{array}{l}\text { Anping, Luermen } \\
\text { (Tainan) }\end{array}$ & Chiayi & 2 & $>10$ & & & $\begin{array}{l}6,7,8,9 \\
10,11,12,13,14\end{array}$ \\
\hline 17 & 29 Oct 1853 & Taiwan east coast & $\begin{array}{l}\text { East of Taiwan- } \\
\text { Ryukyu islands }\end{array}$ & 1 & & & $\begin{array}{l}\text { Volcano- } \\
\text { induced }\end{array}$ & 4,14 \\
\hline 18 & 7 Jun 1862 & $\begin{array}{l}? \text { (Earthquake } \\
\text { at Chiayi) }\end{array}$ & Chiayi & 0 & & & & 15 \\
\hline 19 & 11 Jun 1866 & Kaohsiung & & 0 & & & $\begin{array}{l}\text { Wrong reported } \\
\text { date for } \# 20\end{array}$ & 11 \\
\hline 20 & 16 Dec 1866 & Kaohsiung & "Distant earthquake" & 1 & & & & 9,11 \\
\hline 21 & 11 Jun 1867 & Keelung & & 0 & & & $\begin{array}{l}\text { Wrong reported } \\
\text { date for } \# 22\end{array}$ & 11 \\
\hline 22 & 18 Dec 1867 & Keelung & Keelung/ESC & 4 & 7.5 & "A few hundreds" & & $\begin{array}{l}2,3,4,5 \\
6,7,9,10 \\
11,12,14,15\end{array}$ \\
\hline 23 & 9 Dec 1882 & China & SCS/Kansuh & 0 & & & $\begin{array}{l}\text { "Kansuh" is } \\
\text { an unknown place }\end{array}$ & 3,14 \\
\hline 24 & 7 Sep 1903 & Taiwan & Taiwan & 1 & & & "Probably storm surge" & $4,14,15$ \\
\hline 25 & 25 Jan 1917 & Tongan (Fujian) & $\begin{array}{l}\text { SCS/ECS/ } \\
\text { Taiwan Strait }\end{array}$ & 3 & $\begin{array}{l}0.5 \text { or } \\
2-5.9\end{array}$ & & Same event as \#28? & $\begin{array}{l}2,3,4,5 \\
7,8,11,13 \\
14,15\end{array}$ \\
\hline 26 & 6 May 1917 & $\begin{array}{l}\text { Eastern Taiwan, } \\
\text { Keelung }\end{array}$ & $\begin{array}{l}\text { Taiwan Strait/ } \\
\text { SCS }\end{array}$ & 2 & $\begin{array}{c}0.5 \text { or } 1 \\
\text { or } 3.7\end{array}$ & & Same event as \#29? & $\begin{array}{l}2,4,7,9 \\
11,14,15\end{array}$ \\
\hline
\end{tabular}


Table 3. Continued.

\begin{tabular}{|c|c|c|c|c|c|c|c|c|}
\hline $\begin{array}{l}\text { Event } \\
\text { No. } \\
\text { (\#) }\end{array}$ & $\begin{array}{r}\text { Date } \\
(\mathrm{GMT}+8)\end{array}$ & $\begin{array}{l}\text { Reported } \\
\text { Tsunami } \\
\text { Location }\end{array}$ & $\begin{array}{l}\text { Reported } \\
\text { Source } \\
\text { Location }\end{array}$ & $\begin{array}{l}\text { Vali- } \\
\text { dity }\end{array}$ & $\begin{array}{l}\text { Max. water } \\
\text { height } \\
\text { (m) }\end{array}$ & Death toll & $\begin{array}{l}\text { Remarks/ } \\
\text { comments }\end{array}$ & $\begin{array}{l}\text { Source } \\
\text { databases }\end{array}$ \\
\hline 27 & 4 Jul 1917 & Keelung & East of Keelung & 1 & 3.7 & & & 10 \\
\hline 28 & 13 Feb 1918 & $\begin{array}{l}\text { Tongan (Fujian), } \\
\text { Shantou (Guangdong) }\end{array}$ & Guangdong & 3 & $7.5 ?$ & & & $\begin{array}{l}6,7,8,10 \\
11,12,13 \\
14,15\end{array}$ \\
\hline 29 & 1 May 1918 & Keelung & & 1 & 3.7 & & & 11 \\
\hline 30 & Sep 1921 & Tainan & & 1 & & & & 11 \\
\hline $\begin{array}{l}31 \\
32\end{array}$ & $\begin{array}{r}2 \text { Sep } 1922 \\
12 \text { Nov } 1922\end{array}$ & $\begin{array}{l}\text { Fujian } \\
\text { Keelung }\end{array}$ & $\begin{array}{l}\text { Taiwan } \\
\text { Chile }\end{array}$ & $\begin{array}{l}0 \\
4\end{array}$ & & & & $\begin{array}{l}14,15 \\
2\end{array}$ \\
\hline 33 & 22 Oct 1951 & Hualien & Taiwan & 4 & 0.3 & & & $9,11,14$ \\
\hline 34 & 5 Nov 1952 & Hong Kong & Kamchatka & 2 & 0.15 & & & 1 \\
\hline 35 & 24 May 1960 & $\begin{array}{l}\text { Hong Kong, } \\
\text { Keelung, } \\
\text { Hualien }\end{array}$ & Chile & 4 & $0.38,0.66,0.3$ & & & $1,2,9,10,11$ \\
\hline 36 & 13 Feb 1963 & $\begin{array}{l}\text { Hualien, } \\
\text { Pago Pago } \\
\text { (American Samoa) }\end{array}$ & $\begin{array}{l}\text { East of Taiwan- } \\
\text { Ryukyu islands }\end{array}$ & 4 & 0.2 & $15 ?$ & & $4,11,14,15$ \\
\hline 37 & 13 Oct 1963 & Hualien & Kuril Islands & 4 & $>0.1$ & & & 9,11 \\
\hline 38 & 28 Mar 1964 & Hualien & Alaska & 4 & 0.15 & & & $9,10,11$ \\
\hline 39 & 13 Mar 1966 & $\begin{array}{l}\text { Eastern Taiwan, } \\
\text { Ryukyu Islands (Japan) }\end{array}$ & $\begin{array}{l}\text { East of Taiwan- } \\
\text { Ryukyu islands }\end{array}$ & 4 & 0.1 & $7 ?$ & $\begin{array}{l}\text { People killed } \\
\text { in tsunami } \\
\text { or earthquake? }\end{array}$ & $4,7,11,14,15$ \\
\hline 40 & 25 Jan 1972 & $\begin{array}{l}\text { Eastern Taiwan, } \\
\text { Malakal Harbour (Palau), } \\
\text { Ishigakijima (Japan) }\end{array}$ & $\begin{array}{l}\text { East of Taiwan- } \\
\text { Ryukyu islands }\end{array}$ & 4 & 0.1 & & & $11,14,15$ \\
\hline 41 & 12 Mar 1978 & Lanyu (Taitung) & East of TW & 0 & & & $\begin{array}{l}\text { Wrong reported } \\
\text { date for \#42 }\end{array}$ & 11 \\
\hline 42 & 23 Jul 1978 & $\begin{array}{l}\text { Lanyu (Taitung), } \\
\text { Ishigaki Island (Japan) }\end{array}$ & Taiwan & 4 & 0.1 & & & $11,14,15$ \\
\hline 43 & 15 Nov 1986 & Hualien, Yilan & East of Taiwan & 4 & 0.3 or 2 & & & $10,11,14,15$ \\
\hline 44 & 29 Feb 1988 & Xiamen (Fujian) & Northern Pacific & 2 & 0.34 & & & 11 \\
\hline 45 & 24 Jun 1988 & Hong Kong & Luzon Strait & 3 & 0.28 & & & 12,14 \\
\hline 46 & 14 Dec 1990 & $\begin{array}{l}\text { Miyakojima, Ishigakijima } \\
\text { (Japan) (Earthquake at Taiwan) }\end{array}$ & Taiwan & 4 & 0.04 & & $\begin{array}{l}\text { No report of hitting } \\
\text { although source } \\
\text { at Taiwan }\end{array}$ & 14,15 \\
\hline 47 & 8 Aug 1993 & Hualien, Changkang & Near Guam & 4 & $0.29,0.27$ & & & 11 \\
\hline 48 & 16 Sep 1994 & $\begin{array}{l}\text { Dongshan (Fujian), } \\
\text { Penghu (Taiwan) }\end{array}$ & Near Dongshan & 4 & $0.18-0.47$ & & & 11,12 \\
\hline 49 & 17 Feb 1996 & Changkang, Keelung & Eastern Indonesia & 4 & $0.55,0.25$ & & & 11 \\
\hline 50 & 6 Sep 1996 & $\begin{array}{l}\text { Geng Fang, } \\
\text { Su-ao (Yilan), } \\
\text { Changkang (Taitung) }\end{array}$ & South of Lanyu & 4 & $0.06,0.08,0.22$ & & & 11 \\
\hline 51 & 4 May 1998 & $\begin{array}{l}\text { Lauyu (Taitung), } \\
\text { Miyakojima, Ishigakijima } \\
\text { and Okinawa (Japan) }\end{array}$ & Southeast of Hualien & 4 & 0.07 or 0.13 & & & 11,14 \\
\hline 52 & 21 Sep 1999 & $\begin{array}{l}\text { Sun Moon Lake (Taiwan) } \\
\text { and Okinawa (Japan) }\end{array}$ & WSW of Sun Moon Lake & 4 & 0.21 & & & 11,15 \\
\hline 53 & 2 Nov 1999 & ? (Earthquake at NE of Taiwan) & Northeast of Taiwan & 1 & & & & 15 \\
\hline 54 & 27 Nov 1999 & Taipei county, Su-ao (Yilan) & Vanuatu & 4 & $0.09-0.38,0.11$ & & & 11 \\
\hline 55 & 18 Dec 2001 & Hualien, Ryukyu islands (Japan) & Taiwan & 4 & $0.1-0.16$ & & & 11,14 \\
\hline 56 & 31 Mar 2002 & $\begin{array}{l}\text { Hualien, Iriomote, } \\
\text { Ishigaki, } \\
\text { Yonaguni (Japan) }\end{array}$ & Taiwan & 4 & $\begin{array}{l}0.19-0.27 \\
\quad \text { or } 0.2\end{array}$ & & & $11,14,15$ \\
\hline 57 & 10 Dec 2002 & Eastern Taiwan & East of Changkang & 4 & $0.10-0.59$ & & & 11 \\
\hline 58 & 26 Dec 2006 & China, Hong Kong & Taiwan & 4 & 0.07 & & & 14 \\
\hline
\end{tabular}


The dates for 3 events (\#13, \#25, and \#26) are particularly uncertain. The tsunami reported at Macau on 22 November 1767 (\#13) is possibly the same event as the May 1765 tsunami (\#12) at Guangzhou (Berninghausen, 1969; Cox, 1970; Lee, 1988). For the 25 January 1917 event (\#25), Wang et al. (2005) suggested that reports could be referring to a tsunami on 13 February 1918 (\#28). Most databases also report a tsunami at Keelung in NE Taiwan on the 6 May 1917 (\#26) but Yü (1994) expressed doubt about its validity. Yü (1994) noted that various dates have been suggested for this event, before indicating that it is likely to have occurred on 27 March 1918 as Zheng and Yeh (1989) found that "the only hazardous earthquake within these two years" occurred on this day.

The information presented in Table S1 was condensed and assessed to provide a historical database of 58 possible tsunamis. Details for each event and a validity score assigned based on descriptions given in multiple source catalogues are given in Table 3. Table 5 summarizes the number of reported tsunamis for each assigned validity score. Twenty-three tsunamis were assessed as valid (score of "4"). Many of these events occurred after 1922, as there are better and more precise records. The eighteen events that scored " 1 " in validity formed the second largest group, indicating that there is considerable doubt in the historical records of tsunamis. This is due to very inconsistent information or a lack of supporting evidence. In comparison, a score of " 0 " (invalid) was assigned to eight that were only mentioned in one to two source catalogues. They contained either vague information or descriptions that indicated storm surge events were a more likely source. Notably most of these events have already been marked as false or erroneous entries in the primary source catalogues.

Aside from the two earliest events in 1076 and 1353, the other 56 reported events occurred in or after 17th century with 6 in the 17th, 8 in 18th, 7 in 19th, 31 in 20th, and 4 in 21st century (Fig. 2). The latest tsunami (up to 2009) to hit the NE of the SCS was in 2006, for which a water level of 5-7 cm above normal tide level was detected in SE China and Hong Kong after an earthquake at Taiwan.

Excluding 8 events we assessed as invalid (validity score 0 ), the event on 2 November 1999 (\#53) is the only one with unstated location. The NTL online database is the only source database reporting this event, with a source region of "NE of Taiwan (Lat. 23.38/Long. 121.52)" suggested but the location of any tsunami is not described. For other tsunamis with reported locations, 3 affected both the coasts of China and Taiwan, while 13 events were observed only at the Chinese coast. Thirty-two events were recorded only at Taiwan, and the tsunami on 14 December 1990 (\#46) generated by earthquake at Taiwan was only detected in Japan. On the Chinese coast, observations of tsunamis were recorded at the southern Guangdong cities near Guangzhou, eastern Guangdong cities around Shantou and near the city of Xiamen in the Province of Fujian. Four to five tsunamis were recorded
Table 4. Values quantifying historical tsunami validity rating parameters in Caribbean Tsunami History (after O'Loughlin and Lander, 2003, p. 25).

\begin{tabular}{cl}
\hline Validity score & Quantifying definition \\
\hline 0 & Tsunami did not occur \\
(Invalid) & $\begin{array}{l}\text { Erroneous or invalid information } \\
\text { Record of other inundation mechanism, } \\
\text { e.g. storm surge, spring tides }\end{array}$ \\
& Single record with no supporting record \\
1 & Unlikely or improbable tsunami occurrence \\
(Doubtful) & $\begin{array}{l}\text { Information assessed as unreliable, vague or } \\
\text { of doubtful authenticity, }\end{array}$ \\
& Tsunami cannot be ruled out entirely \\
2 & Tsunami may or may not have occurred \\
Some question about the event or report, \\
data are unclear or insufficient to authenti- \\
cate a tsunami occurrence, particularly in \\
the pre-instrumental period \\
Likely or probable tsunami occurrence \\
Reliable observations for corroboration \\
are few but consistent \\
Trobable)
\end{tabular}

Table 5. Number of reported tsunamis for each assigned validity score from 0 (invalid) to 4 (valid).

\begin{tabular}{lc}
\hline Validity score & $\begin{array}{c}\text { Number } \\
\text { of events }\end{array}$ \\
\hline 0 (Invalid) & 8 \\
1 (Doubtful) & 18 \\
2 (Possible) & 6 \\
3 (Probable) & 3 \\
4 (Valid) & 23 \\
\hline
\end{tabular}

at each of these clusters of cities. On the Taiwanese coast, 18 reported historical tsunamis were found to have struck eastern Taiwan (where Hualien and Taitung are), making it the most affected coast on the island and in the region. Nine events were recorded in SE Taiwan including counties of Tainan and Kaohsiung and the Penghu Island. Nine events were observed to have struck northern Taiwan mainly at Keelung (Fig. 1).

Focusing on the 23 "valid" tsunamis in the area, we found one event in each of the years 1867,1922 , and 1951, followed by 5 tsunamis in the 1960s, 2 in 70s, 1 in 80s, 8 in 90 s, and 4 since 2000. While 2 valid tsunamis were detected on both the coasts of China and Taiwan, 19 were recorded 
(a)

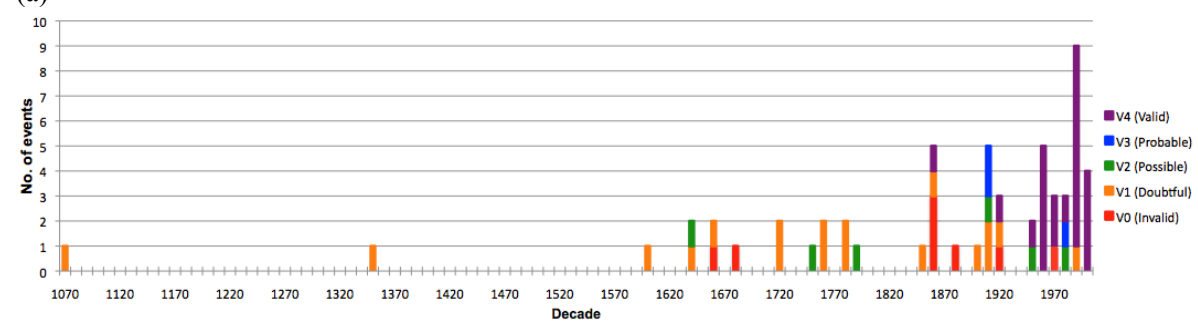

(b)

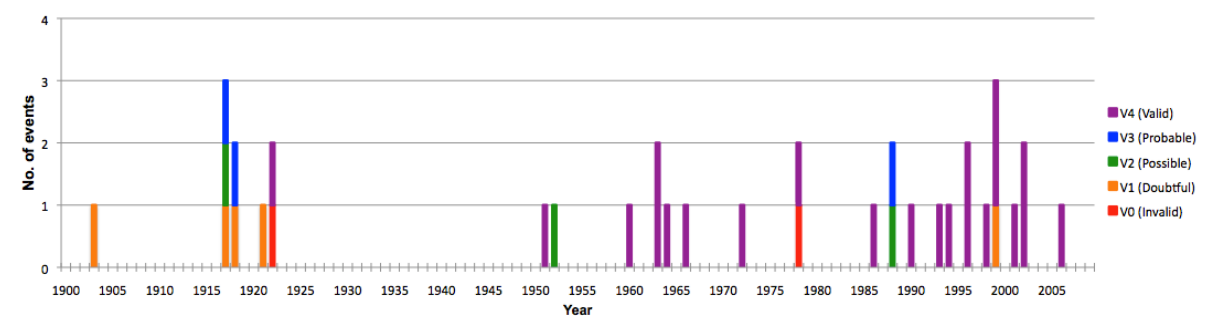

Fig. 2. Temporal distribution of reported historical tsunamis, with assigned validity scores, in the NE SCS region. More valid tsunamis are reported since 1950s as tide gauge stations are available to show sea level changes. (a) All historical events reported in the region, covering since AD 1076. Horizontal axis is in decade starting AD 1070. (b) Distribution of reported historical tsunamis from AD 1900-2009 given in year.

only on the Taiwan coast and one only affected the Chinese coast. The other was a tsunami that was only observed in Japan after an earthquake near Taiwan. Of the 19 tsunamis at Taiwan, 9 were found to have affected Hualien and 4 affected Keelung. There are 2 relatively widely observed valid tsunamis in the area. The 1960 Chile earthquake generated a tsunami that arrived at Hong Kong, Keelung and Hualien two days after the earthquake (\#35). In contrast to this far-field or teletsunami, the 1994 local earthquake near Dongshan in Fujian Province also generated a tsunami that affected both the Chinese and Taiwanese coasts at Dongshan and Penghu respectively (\#48).

The most disastrous valid tsunami is the 1867 Keelung event (\#22). Waveheights of $7.5 \mathrm{~m}$ and a few hundred deaths were recorded in historical records (Iida et al., 1967; Yang, 1987; Wang et al., 2005; Wong and Chen, 2006; NGDC database, 2009). A 1966 event was reported as a very weak tsunami on the Ryukyu and Kyushu islands of Japan (Soloviev and Go, 1974; NGDC database, 2009) as a result of a strong earthquake, yet Yang (1987) has reported this as a moderate tsunami that drowned 7 people (location not mentioned), citing Iida (1967) as the source. All other valid tsunamis that affected the NE of the SCS were not fatal or particularly destructive, and are recorded as water level changes in the order of tens of centimeters measured by tide gauges.

\section{Discussion}

In this study, 58 possible historical tsunami events in the $\mathrm{NE}$ region of the SCS were identified from a number of catalogues and databases. Disregarding 8 invalid events, a suggested source location was not found for 3 reported events (\#2, \#29, and \#30). Of the other reported events, 36 are likely local events with tsunami generated at locations within $3 \mathrm{~h}$ of tsunami travel time from the area. These source locations include the SCS, China, Taiwan, the Ryukyu Islands and the Luzon Strait. The other 11 are teletsunamis with sources at Chile, the Kuril Islands, Alaska, the northern Pacific, Guam, Indonesia or Vanuatu, while two notes of "distant earthquake" are proposed as the tsunami sources by Yü (1994) for tsunamis \#14 and \#20 without specific locations reported.

When entries from existing tsunami catalogues and databases for the region were listed and compared, it becomes apparent that this region lacks an accurate, representative and comprehensive regional database of historical tsunami events.

\subsection{Validity assessment}

The development of a historical tsunami database allows a validity assessment by comparing reports made about the same tsunami in different source databases. Some examples are described here.

Events with contrasting validity marks assigned in different source catalogues require extra attention and investigation. For example, although the NTL database has validated the May 1765 event (\#12) as a “definite tsunami”, Lee (1988) 


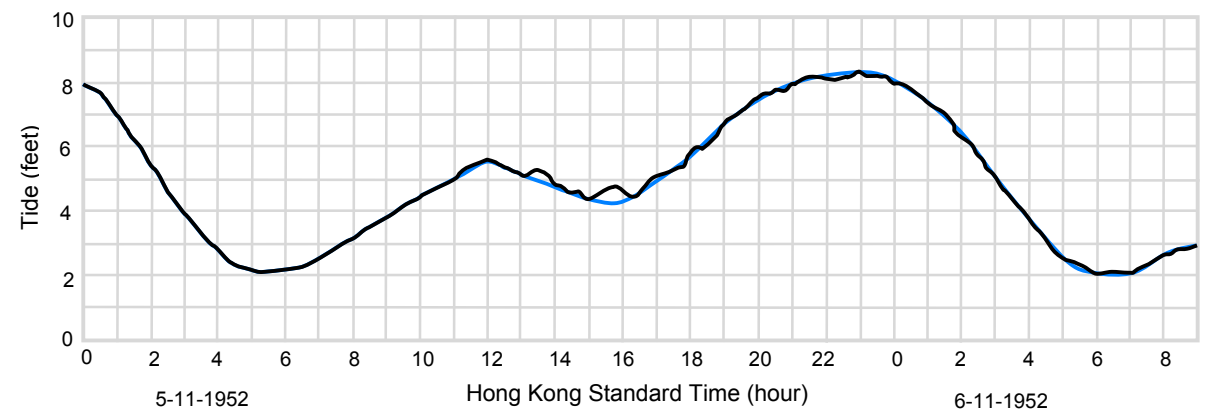

Fig. 3. Tide gauge record of the 1952 Kamchatkan Tsunami at North Point, Hong Kong. Tsunami height of 6 inches (15 cm), as black line shows, was noted by Royal Observatory, Hong Kong (now Hong Kong Observatory) (adapted from Cheng, 1965, p. 15). The expected normal water level is exhibited by the blue line.

recorded the event as "very doubtful" partly owing to the absence of an earthquake. The NGDC went further and listed it as an "erroneous entry" suggesting that the event was "probably meteorological". We have thus assigned a validity score of 1 to this event after regarding comments in previous works as this may be a storm surge event. While the possibility of a tsunami cannot be ruled out completely, more detailed research is required before confirming the nature of this event.

The number of source catalogues reporting each event is another factor controlling validity assessment. In particular, events which were only reported in one or two sources are often doubted. With the exception of relatively recent events, most events with only one entry are considered erroneous or invalid. Notably, most of the events with a single entry are from the NGDC or NTL online databases. This may be due to mistranslation or misinterpretation of written records. Most of the solely reported events in these two databases have already been marked as "erroneous entry" or "false entry" in the online databases. Examples can be found in Table S1, including the 1660 event (\#6, appeared in NGDC database, 2009) and 2 September 1922 event in Fujian, China (\#31, recorded in both online databases).

Some events such as those being solely reported in a single Chinese publication require more investigation. An example is the 4 July 1917 event (\#27) recorded by Wang et al. (2005). More research is needed for validation since no validity score or source of information were listed in that catalogue. Wang (2005) describes "an earthquake with magnitude of 7.3 in the sea east of Keelung that generated a $3.7 \mathrm{~m}$ high tsunami wave" (p. 440, in Chinese). But no record of an earthquake on that date is found in any of the major earthquake catalogues. As such the tsunami is considered invalid (score of 0 ) before further evidence appears.

The 5 November 1952 event (\#34) is another example. The "technical note (local) of the Royal Observatory, Hong Kong" by Cheng (1965) is the only report of the Kamchatkan tsunami arrival to the coastline of the NE region of the SCS. The tide gauge record of the Royal Observatory, Hong Kong (now Hong Kong Observatory) shows an unusual fluctuation in water level of maximum amplitude of 6 inches $(15 \mathrm{~cm})$ from crest to trough on 5 November 1952 (Fig. 3), about $12 \mathrm{~h}$ after the $M 9$ earthquake (reported as $M 8.2$ by Cheng, 1965) at Kamchatka, Russia. Although this event is clearly supported by tide gauge data, the effects on the NE SCS region remain uncertain due to the lack of reports from more proximal locations other than Hong Kong.

Three events dated 11 June 1866 (\#19), 11 June 1867 (\#21), and 12 March 1978 in a table by Li et al. (2006, p. 404) apparently arose from incorrect reporting, thus they are also categorized as invalid entries in our database. In the research of Li et al. (2006), 40 reported tsunamis were described and discussed, followed by a table summarizing all mentioned events. In their work, Li et al. (2006) reported three tsunamis on 16 December 1866 at Kaohsiung (\#20), 18 December 1867 at Keelung (\#22), and 23 July 1978 at Lanyu (\#42) that are correctly described in the text. However, the dates for the events appear to be wrongly listed in the accompanying table. The inaccurately reported events require extra attention as there is at least one publication ( $\mathrm{Li}$ and $\mathrm{Hsu}, 1999)$ that presented the same table with incorrect dates for these three events. Moreover, no other descriptions or dates for the original tsunami events we list as \#20, \#22, and \#42 are included in the work by Li and Hsu (1999). Once again this clearly demonstrates that the comparison of entries from multiple databases and catalogues is essential.

\subsection{Spatial and temporal distribution of events}

Taiwan is more susceptible to tsunami than the mainland Chinese coast. The city most frequently affected by valid tsunamis is Hualien in eastern Taiwan with nine events since 1951, followed by Keelung in northern Taiwan with three events. Hualien is the city with most tsunamis primarily because it is more susceptible to teletsunamis from across the Pacific Ocean. Notably none of these historical tsunamis was particularly fatal or disastrous as they were all minor tsunamis detected by tide gauge instruments after 1950. In contrast, Tainan and Kaohsiung in SW Taiwan are the cities 
Table 6. Probability of the northeast SCS region being affected by tsunamis, calculated from the occurrence of historical tsunamis in the region using Poisson probability calculations. Note 1 - Besides \#35 (0.3-0.66 m), \#43 (0.3 or $2 \mathrm{~m})$, \#49 (0.25-0.55 m) and \#57 (0.10-0.59 m), all other events are with wave heights $<0.5 \mathrm{~m}$. Refer to Tables $\mathrm{S} 1$ and 3 for events details.

\begin{tabular}{|c|c|c|c|c|}
\hline Category & $\begin{array}{l}\text { Reported } \\
\text { historical } \\
\text { events \# }\end{array}$ & $\begin{array}{l}\text { No. of } \\
\text { reported } \\
\text { events }\end{array}$ & $\begin{array}{l}\text { Probability } \\
\text { of having } 1 \text { or } \\
\text { more such event } \\
\text { in a year }\end{array}$ & $\begin{array}{l}\text { Probability of } \\
\text { having } 1 \text { or } \\
\text { more such even } \\
\text { in } 100 \text { years }\end{array}$ \\
\hline \multicolumn{5}{|l|}{$\begin{array}{l}\text { Case 1. The region being hit by significant tsunami } \\
\text { (time period 1076-2009) }\end{array}$} \\
\hline $\begin{array}{c}\text { Calculation 1: reported tsunamis with recorded } \\
\text { wave heights of }>2 \mathrm{~m}\end{array}$ & $\begin{array}{l}12,14,15,16 \\
22,25,26,27 \\
28,29,43\end{array}$ & 11 & $\begin{array}{l}0.012 \\
(=1.2 \%)\end{array}$ & $\begin{array}{l}0.692 \\
(=69.2 \%)\end{array}$ \\
\hline $\begin{array}{c}\text { Calculation 2: reported tsunamis with recorded } \\
\text { wave heights of }>1 \mathrm{~m}\end{array}$ & $\begin{array}{l}7,12,14,15 \\
16,22,25,26 \\
27,28,29,43\end{array}$ & 12 & $\begin{array}{l}0.013 \\
(=1.3 \%)\end{array}$ & $\begin{array}{l}0.723 \\
(=72.3 \%)\end{array}$ \\
\hline $\begin{array}{l}\text { Calculation 3: reported tsunamis with recorded } \\
\text { wave height data of }>1 \mathrm{~m} \text {, plus events } \\
\text { with no wave height data but damage } \\
\text { to houses or deaths on land mentioned }\end{array}$ & $\begin{array}{l}1,3,7,9,10,11 \\
12,14,15,16,20 \\
22,25,26,27,28 \\
29,35,36,39,43\end{array}$ & 21 & $\begin{array}{l}0.022 \\
(=2.2 \%)\end{array}$ & $\begin{array}{l}0.894 \\
(=89.4 \%)\end{array}$ \\
\hline $\begin{array}{l}\text { Calculation 4: events in calculation } 3 \text { with validity or } \\
4 \text { scores of } 2,3 \text { (possible, probable and } \\
\text { valid tsunamis) }\end{array}$ & $\begin{array}{l}11,16,22,25 \\
26,28,35,36 \\
39,43\end{array}$ & 10 & $\begin{array}{l}0.011 \\
(=1.1 \%)\end{array}$ & $\begin{array}{l}0.657 \\
(=65.7 \%)\end{array}$ \\
\hline $\begin{array}{l}\text { Case 2. Any tsunami waves arriving in the region } \\
\text { (with validity scores } 2,3 \text { or } 4 \text { in time } \\
\text { period } 1951-2009 \text {, years with } \\
\text { instrumental measurements) }\end{array}$ & $\begin{array}{l}33-58 \text { except } 41 \text { and } 53 \\
\text { (see note } 1 \text { ) }\end{array}$ & 24 & $\begin{array}{l}0.334 \\
(=33.4 \%)\end{array}$ & - \\
\hline
\end{tabular}

that have been hit by several damaging and fatal yet unvalidated older tsunamis. This includes tsunamis in 1721 (\#10, at Tainan), 1781 and 1782 (\#14, \#15, both at Kaohsiung) that all resulted in a great number of casualties. Wave heights of historical tsunamis recorded along the coast of SW Taiwan were also significantly higher than those recorded in eastern Taiwan. Several reports (e.g. Yang, 1987; NGDC database, 2009; NTL database, 2009) indicate that the 1781 and 1782 Kaohsiung and 1792 Tainan tsunamis (\#16) had wave heights of 10 to $30+\mathrm{m}$. This contrasts to eastern Taiwan (e.g. at Hualien) where water heights of less than $1 \mathrm{~m}$ have been recorded in history.

The most fatal tsunami reported on the Chinese coast is the 1765 tsunami (\#12) at Guangzhou, for which wave heights of $9 \mathrm{~m}$ and a death toll of $>10000$ are reported (Berninghausen, 1969; Soloviev and Go, 1974; Lee, 1988; Mak and Chan, 2007; NGDC database, 2009). Although this is the deadliest tsunami event in the region we found that this part of the Chinese coast was less frequently affected by tsunamis than cities to the east including Shantou and Xiamen.

More tsunamis were recorded in the 20th century (Fig. 2) because more instruments have become available to detect water level changes caused by minor and weak tsunamis that caused only small variations in sea level. This results in more frequent "events" but a dominance of lower wave heights (Geist and Parsons, 2006) since the 1950s. Conversely, older recorded historical tsunamis (until early 20th century) are likely to be stronger events, as the increased sea level had to be significant enough for people to recognize it without instruments.

With the change in tsunami observation method from visual to instrumental, it is difficult if not impossible to construct a uniform database (Geist and Parsons, 2006). Consequently, there are considerable difficulties in deducing the recurrence interval of tsunami in the region. In order to statistically predict the occurrences of tsunamis in the future, a few elementary Poisson probability calculations were undertaken (Table 6) for the region.

Based on the occurrence of historical tsunamis in the record, the probability of having one or more significant tsunami (calculated with wave heights $>2 \mathrm{~m},>1 \mathrm{~m}$, and/or caused damages to houses and fatalities) affecting the region in a year is $1-2 \%$, with an associated $69-90 \%$ chance of occurrence in any century (Table 6). This finding is much higher than the prediction by Liu et al. (2007) based purely on linear and nonlinear models of earthquake generated tsunami from the Manila Trench. Liu et al. (2007) suggested that the chances of $>2 \mathrm{~m}$ tsunami to hit Hong Kong 
and Macau, Kaohsiung, and within the coming 100 years are $10.12 \%, 3.40 \%$, and $10.12 \%-13.34 \%$, respectively. On the contrary, analysis of the occurrence of recent tsunamis (1951-2009) measured by tide gauges indicates that the probability of having one or more tsunami of any wave height in the region during any given year is as high as $33.4 \%$.

Although the basic statistics indicate that the likelihood of a tsunami somewhere in the region in any given year is high the historical record clearly indicates a dominance of small $(<1 \mathrm{~m})$ tsunami events. Except for event \#43 where a wave height of $2 \mathrm{~m}$ was reported at Hualien (Hsu, 1994), all tsunamis within the 1951-2009 period have wave heights of less than $1 \mathrm{~m}$ and are mostly $<0.5 \mathrm{~m}$. From the annual probability of $33.4 \%$, we can conclude that the recurrence interval of tsunami waves in the region is approximately 3 years. While the latter determination of probability based on recent tsunamis is more accurate and reliable, the error for the earlier calculation of major tsunami occurrences with time period 1076-2009 is large as many older reported events are too inconsistent and doubtful. For example, several reported events (e.g. \#1, \#10,\#12) with significant wave heights have been regarded as possibly of meteorological origin by previous researchers. However, it is still clear that the historical data available suggest that the chance of the region being hit by large, fatal and destructive tsunamis is low.

\subsection{Cross-checking}

Cross-checking information about historical tsunamis from multiple sources is important and necessary, to recognize inconsistencies and contradictions in details of events. In particular, misinterpretations, mistakes and errors in translation or the inaccurate citing of previous works can be analysed (Gusiakov, 2009). The most common errors we encountered were inconsistency in death toll, contradictory descriptions, consistently vague descriptions or incorrect citations and misinterpretation. In this section we highlight some problems encountered in developing our database.

\subsubsection{Inconsistency in death toll}

The event in the database that best illustrates the inconsistency in reporting death tolls is the 1781 event (\#14) in SW Taiwan. The reported number of fatalities associated with this event that occurred between April and June 1781 is inconsistent between all entries. Three out of four entries that record this event provide details of a tsunami. The death of one woman was reported in 2 entries with reference made to "Taiwan interview catalogue" (Chen et al., 1830). In contrast, Yang (1987) recorded $>50000$ deaths associated with a tsunami caused by a Taiwan Strait earthquake in May. In citing $>50000$ deaths Yang also quoted descriptions from Chen et al. (1830). The death toll reported for this event appears erroneous since it is not cited in the detailed publications of Soloviev and Go (1974), and Zhou and Adam (1986). How- ever, the inclusion of the 1781 tsunami-like event into the work of Yang (1987) has been generally accepted and this "deadly" tsunami report is now widely quoted among Chinese literatures (e.g. Wang and Bao, 1992; Ye et al., 2005).

\subsubsection{Contradictory descriptions for an event}

The 9 August 1792 event (\#16) at Tainan is recorded in 9 out of 15 source catalogues reviewed. Most of the entries describe unusual wave action in calm conditions. For example, the following description was provided by Zhou and Adams (1986, p. 139) as translated from Gu et al. (1983): "Water was uplifted several meters without wind, the field slumped down and water flooded in lower" (direct translation). Similarly, Yü (1994) recorded the event as "after an earthquake in the month, ships at Luermen were

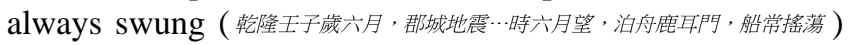
... suddenly when there was no wind, water surged up a few zhangs ( 1 zhang is about $3.3 \mathrm{~m}$ ) high (忽無風, 水涌起數丈)...” by directly citing the work of Xu (1983). However, in a study of historical earthquakes in China, Mak and Chan (2007) presented a contrasting finding for this event. While they also noted that "ships were shaken" at Luermen after a significant earthquake (Chen et al., 1830; Chen, 1968), they found that although the damage of this earthquake was reported in an official document (The State Archives Administration of the PRC, 1959), "no condition of the sea was reported" (p. 129).

\subsubsection{Suspicious or erroneous reporting of unusual events}

The Yang (1987) record of the 1781 April-June event (\#14) is possibly the best example of how erroneous reporting can arise when including information from previous publications. In this entry, Yang outlines many details including a "tsunami" that "lasted for 1-8h" from which "over 50000 people died" at "Taiwan and Taiwan Strait". The descriptions are similar to those for the 22 May 1782 event (\#15) recorded for Taiwan by Iida et al. (1967) and Soloviev and Go (1974). Therefore, it appears very likely that Yang (1987) mixed details of the 1782 event with that of 1781 when composing the tsunami event list.

\subsubsection{Incorrect citations}

Lee (1988) cited the publication of Zhou and Adams (1986) as one of the data sources for a tsunami event on the SE Chinese coast on 16 September 1640 (\#4). However, it appears that Zhou and Adams have not included this event in their work. Interestingly they have reported a tsunami at the same location and similar dates for the year 1641 (\#5).

\subsubsection{Misinterpretation of previous works}

Referring to the work of Soloviev and Go (1974), Mak and Chan (2007) made the following description of an event 
listed as occurring on 22 May 1782 (\#15): "It was reported that Taiwan was shaken by an earthquake, associated with a flood extended $120 \mathrm{~km}$ for inland, and 40000 casualties was claimed (Perrey, 1862a, cited by Soloviev et al., 1974)" (p. 158). Regarding the size and relief of the island of Taiwan and the actual power a tsunami can have, it is highly unlikely that a flood can extend $120 \mathrm{~km}$ inland. In the original report by Soloviev and Go (1974), "Almost the entire island was flooded for a distance of more than $120 \mathrm{~km}$ (30 leagues)" was stated. It appears more appropriate to interpret it as "more than $120 \mathrm{~km}$ of coastline was flooded" since this is more probable. However, as "almost the entire island" was mentioned in the original text, we cannot completely rule out the possibility that the flood has extended $120 \mathrm{~km}$ inland. If true, however, this event would be by far the greatest inundation distance ever recorded, thus making this event the most powerful tsunami of all time. Another possibility is the event was caused by an extraordinarily hazardous catastrophe other than a tsunami. This confusion clearly illustrates how the ambiguity of information presented in earlier publications makes tsunami verification more challenging.

\section{Regional correlation of events across the Taiwan Straits}

According to the records examined, several significant historical "tsunamis" have occurred on both the Chinese and Taiwanese coasts. Although the occurrences of these main events are mostly doubted due to inconsistencies, they should still be highlighted and receive extra investigations as they may be linked to failures in the Manila Trench or other fault systems offshore (Fig. 1).

\subsection{Chinese coast}

Three main events on the Chinese coast are believed to be comparatively destructive. They are the May 1765 event (\#12) where the sea is reported to have risen to $9 \mathrm{~m}$ at Guangzhou with no earthquake reported, killing approximately 10000 people; the unusual tides that damaged many fishing boats at Tongan of Fujian on 25 January 1917 (\#25); and another event at Shantou and Tongan on 13 February 1918 (\#28). Doubts for these events exist as Wang et al. (2005) believe that 25 January 1917 (as for \#25) is the mistakenly reported date of the 13 February 1918 tsunami (\#28). Thus, even though these events have assigned validity score of 3 (probable tsunamis), together with the other main "tsunami" events they require more comprehensive research and field surveys.

\subsection{Taiwanese coast}

From the database, three major destructive events are identified. Due to inaccuracies and inconsistencies these are all assigned a score of 1 (doubtful). Despite this they are all reported to have considerable death tolls. This includes the September 1721 event (\#10) of an earthquake together with "strange wind and rainstorm", causing thousands deaths at Tainan (Lee, 1988; Mak and Chan, 2007; NGDC database, 2009); the event in April June 1781 (\#14), which is reported to have killed either 1 woman or $>50000$ people in Pingtung or Kaohsiung; and an event that caused a violent rise in sea level with or without a preceding earthquake, leading to flooding of Taiwan on 22 May 1782 (\#15) which have caused $>40000$ casualties on Taiwan (and mainland China as well according to Iida et al., 1967). The 1721 (\#10) and 1782 (\#15) events were judged to be "possibly storm surges" in previous catalogues (e.g. Zhou and Adams, 1986 for \#10, Iida et al., 1967 for \#15).

A research program of historical tsunamis would not be complete without the investigation of geological records. For major tsunamis that have caused extensive flooding or significant death tolls, it is likely that tsunami deposits will record the event in the landscape. This review identifies several key locations to investigate palaeotsunami and compare historical notes to the recent geological record therefore allowing the identification of regionally significant events (Goff and Dominey-Howes, 2009).

\section{Conclusions}

The historical tsunami database for the NE region of the SCS contains approximately 58 possible events from year 1076 to 2009 that were reported in the 15 examined source catalogues. Uncertainty in the number of events is due to inconsistencies or multiple dates being marked for some events. Of the reported events, 23 are considered valid tsunamis, 3 were probable, 6 possible tsunamis, 18 doubtful and 8 invalid. Based on historical records from 1951 to 2009 the likelihood of the region being hit by a tsunami from any source in any given year is high (33.4\%). However, the probability of a tsunami that has wave heights $>1 \mathrm{~m}$, and/or caused damages to houses and fatalities occurring in the region in any given year is much lower at approximately $1-2 \%$.

Comparison of reported details among entries of each event provides a basis for validity assessment. By crosschecking data from various sources, inaccurate information presented and erroneous reports are identified and a judgment in verification has been made. Although the validity of each reported event was assessed based on details available, further investigation into the geological record is deemed necessary before confirming or rejecting each of the reported tsunami. This is particularly the case for the reported disastrous "tsunamis" that occurred in southern Taiwan in Tainan, Kaohsiung and Pingtung and SE China in Guangzhou, Shantou and Tongan. This historical tsunami database presents a compilation of historical records that can be used to guide fieldwork for geological studies of historical tsunamis in the NE region of the SCS. 


\section{Supplementary material related to this article is available online at: \\ http://www.nat-hazards-earth-syst-sci.net/10/1793/2010/ nhess-10-1793-2010-supplement.pdf.}

Acknowledgements. We would like to thank W. K. Li of the Department of Statistics \& Actuarial Science of The University of Hong Kong for his advice on statistics. This material is based on research supported in part by the Singapore National Research Foundation under NRF RF Award No RF2010-04 to A. D. Switzer, Research Grants Council of the Hong Kong Special Administrative Region, China (project HKU 704008P) to A. D. Switzer and Dominey-Howes, and an Earth Observatory of Singapore grant to A. D. Switzer. A. Y. A. Lau is supported by a HKU-Space postgraduate scholarship. Chiu Hon Chim is thanked for his help with an early draft. This work is Earth Observatory of Singapore Contribution Number 8.

Edited by: S. Tinti

Reviewed by: two anonymous referees

\section{References}

Berninghausen, W. H.: Tsunamis and seismic seiches of Southeast Asia, B. Seismol. Soc. Am., 59(1), 289-297, 1969.

Bryant, E.: Tsunami: the underrated hazard, Springer-Praxis, Chichester, 330 pp., 2008.

Chen, G. Y. and other 15 interviewers: Taiwan Interview Catalogue, 1830 (in Chinese).

Chen, S. Q.: Fujian historiography, Hua-Wen Bookstore, Taipei, 1968 (in Chinese).

Cheng, T. T.: Tsunamis, Hong Kong Observatory Technical Note (Local) No. 7, Hong Kong Observatory, Hong Kong, 1965.

Cox, D. C.: Discussion of 'Tsunamis and seismic seiches of Southeast Asia' by William H. Berninghausen, B. Seismol. Soc. Am., 60(1), 281-287, 1970.

Dominey-Howes, D.: Documentary and geological records of tsunamis in the Aegean Sea region of Greece and their potential value to risk assessment and disaster management, Nat. Hazards, 25, 195-224, 2002.

Dominey-Howes, D.: Geological and historical records of tsunami in Australia, Mar. Geol., 239(1-2), 99-123, 2007.

Geist, E. L. and Parsons, T.: Probabilistic Analysis of Tsunami Hazards, Nat. Hazards, 37, 277-314, 2006.

Goff, J. and Dominey-Howes, D.: Australasian palaeotsunamis do Australia and New Zealand have a shared trans-Tasman prehistory?, Earth-Sci. Rev., 97, 159-166, 2009.

Goff, J. R.: The New Zealand Palaeotsunami Database, NIWA Technical Report 131, 24 pp., 2008.

Gu, G. X., G., Lin, T. H., Si, Z. L., Li, Q., Wu, H. Y., Lu, S. D., Yang, Y. L., Chen, H. T., and Wang, S. Y.: Catalog of Earthquakes in China, National Bureau of Seismology, 894 pp., 1983 (in Chinese).

Gusiakov, V. K.: Tsunami History: Reocrded, in: The SeaTsunamis, Harvard University Press, Cambridge, 23-53, 2009.

Heck, N. H.: List of seismic sea waves, B. Seismol. Soc. Am., 37(4), 269-286, 1947.
Heck, N. H.: List of seismic waves, Annales de la Commission pour l'Etude des Raz de Maree, 4, 20-41, 1934 (in French).

Iida, K.: Catalog of tsunamis in Japan and neighboring countries, Special Report, Yashigasa, Aichi Institute of Technology, 52 pp., 1984.

Iida, K., Cox, D. C., and Pararas-Carayannis, G.: Preliminary Catalog of Tsunamis Occurring in the Pacific Ocean, HIG-67-10, Hawaii Institute of Geophysics, University of Hawaii, Honolulu, Hawaii, 275 pp., 1967.

International Tsunami Information Centre (n/d, ITIC): List of Tsunamis, available at: http://ioc3.unesco.org/itic/categories. php?category_no=77 (last access: April 2010), 2010.

Jan, S., Chern, C. S., and Wang, J.: Transition of tidal waves from the East to South China Seas over the Taiwan Strait: Influence of the abrupt step in the topography, J. Oceanogr., 58, 837-850, 2002.

Lander, J. F., Whiteside, L. S., and Lockridge, P. A.: Two Decades of Global Tsunamis, 1982-2002, Science of Tsunami Hazards, Science of Tsunami Hazards, Honolulu, Hawaii, USA, 21(1), 3 82, 2003.

Lee, B. Y.: Report by Hong Kong, International Tsunami Seminar in the Western Pacific Region, Tokyo, Japan, 7-12 March 1988.

Li, C. H., Hsu, M. K., Cheng, W. B., Hsiao, S. C., and Lin, Q. L.: Preliminary research on the development of tsunami warning system at northeastern Taiwan, Central Weather Bureau Technical note, 45: Project code MOTC-CWB-95-E-26, 2006 (in Chinese).

Li, Q. and Hsu, M. K.: Tsunamis Attacking Taiwan and its Neighbouring Areas, Recent Developments in World Seismology, Year 1999(1), 8-13, 1999 (in Chinese).

Li, S. B.: China Earthquakes, Earthquake Press, Beijing, 1981 (in Chinese).

Liu, Y., Santos, A., Wang, S. M., Shi, Y., Liu, H., and Yuen, D. A.: Tsunami hazards along Chinese coast from potential earthquakes in South China Sea, Phys. Earth Planet. In., 163, 233-244, 2007.

Lockridge, P. A., Whiteside, L. S., and Lander, J. F.: Tsunamis and tsunami-like waves of the eastern United States, Science of Tsunami Hazards, 20(3), 120-157, 2002.

Lu, R. J.: China Historical Disastrous Sea-surge Record, Ocean Press, Beijing, 295 pp., 1984 (in Chinese).

Mak, S. and Chan, L. S.: Historical tsunamis in South China, Nat. Hazards, 43(1), 147-164, 2007.

National Geophysical Data Center of National Oceanic and Atmospheric Administration (n/d, NGDC database): Historical Tsunami Database from 2000 B.C. to present, available at: http://www.ngdc.noaa.gov/hazard/tsu_db.shtml, last access: May 2009.

National Geophysical Data Center of National Oceanic and Atmospheric Administration (n/d, NGDC): Bathymetry, Topography \& Relief, available at: http://www.ngdc.noaa.gov/mgg/ bathymetry/relief.html (last access: July 2009), 2009a.

National Geophysical Data Center of National Oceanic and Atmospheric Administration (n/d, NGDC): Global Significant Earthquake Database, 2150 B.C. to present, available at: http://www.ngdc.noaa.gov/nndc/struts/form?t=101650 \\&s= $1 \backslash \& d=1$ (last access: July 2009), 2009b.

Novosibirsk Tsunami Laboratory (n/d, NTL database): Historical Tsunami Databases for the World Ocean from 1628 B.C. to present, available at: http://tsun.sscc.ru/On_line_Cat.htm, last ac- 
cess: May 2009.

O'Loughlin, K. F. and Lander, J. F.: Caribbean Tsunamis: A 500-year history from 1498-1998, Kluwer Academic Publishers, Dordrecht, 261 pp., 2003.

Perrey, A.: Documents sur les tremblements de terre et les phenomenes volcaniques au Japon, Mem. Pres. Acad. Imp. Sci., belles-lettres et Lyon, 1862a (in French).

Shyu, J. B. H.: A neotectonic model of Taiwan, with a focus on the Longitudinal Valley Suture, Ph.D. thesis, California Institute of Technology, Pasadena, California, 289 pp., 2006.

Soloviev, S. L, Solovieva, O. N., Go, Ch. N., Kim, K. S., and Shchetnikov, N. A.: Tsunamis in the Mediterranean Sea 2000 B.C.-2000 A.D., Kluwer Academic Publishers, Dordrecht, 237 pp., 2000.

Soloviev, S. L. and Go, Ch. N.: A Catalogue of Tsunamis on the Western Shore of the Pacific Ocean, Nauka Publishing House, Moscow, (Translation by Canada Institute for Scientific and Technical Information, National Research Council, Ottawa, Canada KIA OS2), 1974.

Suppe, J.: Kinematics of arc-continental collision, flipping of subduction, and back-arc spreading near Taiwan, Memoir of the Geological Society of China (Taiwan), 6, 21-33, 1984.

Teng, L. S.: Geotectonic evolution of late Cenozoic arc-continent collision in Taiwan, Tectonophysics, 183(1-4), 57-76, 1990.

The State Archives Administration of the PRC: Historical documents of earthquakes in the Qing Dynasty, Zhonghua Book Company, Beijing, 1959 (in Chinese).

Wang, X. N. and Bao, C. L.: Marine disasters upon China and monitoring-forecasting, Marine Science Bulletin, 11(5), 90-95, 1992 (in Chinese).
Wang, F., Liu, C. S., and Zhang, Z. Q.: Earthquake Tsunami Record in Chinese Ancient Books, Earthquake Research in China, 21(3), 437-443, 2005 (in Chinese).

Wong, W. T. and Chan, Y. W.: Likelihood of tsunamis affecting the coast of Southeastern China, in: 6th General Assembly of Asian Seismological Commission 2006 and Symposium on Earthquake and Tsunami Disaster Preparedness and Mitigation, Bangkok, Thailand, 7-10 November 2006.

$\mathrm{Xu}, \mathrm{M}$. T.: Evaluation of destructive Earthquake magnitude and intensity in Ming and Ching Eras, Meteorological Bulletin, 29(4), 1-18, 1983 (in Chinese).

Yang, W. T.: Tsunami and Pacific tsunami warning system, Marine Forecasts, Year 1987(S1), 68-76, 1987 (in Chinese).

Ye, L., Yu, F. J., and Wu, W.: The disaster and Warning of Tsunami in China and the Suggestion in Future, Marine Forecasts, 22(supplement), 147-157, 2005 (in Chinese).

Y, M. S.: Destructive Earthquake Tsunamis in the Ming and Ching Eras, Meteorological Bulletin, 40(1), 37-46, 1994 (in Chinese).

Zhang, H. N.: Seismic Activity of South China Sea and Evaluation of Regional Stability, in: Geology of the South China Sea, Science Press, Beijing, 456-493, 2002 (in Chinese).

Zheng, S. N. and Yeh, Y. T.: Taiwan earthquake catalogue, A.D. 1604-1988, Institute of Earth Sciences, Academia Sinica, 255 pp., 1989 (in Chinese).

Zhou, Q. H. and Adams, W. M.: Tsunamigenic earthquakes in China: 1831 B.C. to 1980 A.D., Science of Tsunami Hazards, 4(3), 131-148, 1986. 